\title{
O Favor Divino e a Faculdade de Governar: Sobre D. Afonso Henriques de Portugal (1140-1179)
}

\author{
El favor divino y la facultad de gobernar: sobre D. Afonso Henriques de \\ Portugal (1140-1179)
}

Maria Fernanda Ribeiro Tomé Miranda dos Santos ${ }^{1}$

\begin{abstract}
${ }^{1}$ Mestre em História pelo Programa de Pós-Graduação em História da Universidade Estadual do Rio de Janeiro (UERJ) como bolsista CAPES. Licenciada e Bacharel em História pela Universidade Gama Filho (UGF). As áreas de atuação/interesse da pesquisadora são: Ideias Políticas e Cultura da Idade Média, Relações de Poder no Medievo, Realeza Medieval Ibérica, História do Direito, História da Igreja e Ordens Monástico-Militares.
\end{abstract}

Recebido em 26 de março de 2021; Aceito em 3 de julho de 2021.

DOI: $10.12957 /$ nearco.2021.58676

\section{Resumo}

Partindo da premissa que o título usual de referência ao rei medieval, a fórmula Rex Per Gratia Dei, vinculava o poder secular ao poder espiritual cristão, pertencendo a uma antiga linha de argumentos de cunho jurídicos pautados na Bíblia, abordaremos a concepção político-religiosa da "Graça Divina" e a legitimação do poder secular medieval através do estudo de caso de $\mathrm{D}$. Afonso Henriques, primeiro monarca português.

Palavras-chave: Direito Medieval; Realeza; Igreja Católica.

\section{Resumen}

Partiendo de la premisa de que el título habitual de referencia al rey medieval, la fórmula Rex Per Gratia Dei, vinculaba el poder secular al poder espiritual cristiano, perteneciendo a una vieja línea de argumentos jurídicos basados en la Biblia, nos acercaremos de la concepción política-religiosa de la "Gracia Divina" y la legitimación del poder secular medieval através del estudio de caso de D. Afonso Henriques, el primer monarca portugués.

Palabras-clave: Derecho medieval; Realeza; Iglesia Católica. 


\section{Introdução}

Este artigo é parte de minha dissertação de mestrado na qual abordei a trajetória de D. Afonso I utilizando alguns aspectos do conceito weberiano de autoridade legítima. D. Afonso Henriques (1109-1185) foi filho de D. Teresa, ilegítima filha do Imperador Afonso VI de Castela e Leão, e de D. Henrique, pertencente a família ducal da Borgonha. Casou-se com D. Mafalda de Sabóia em 1146, dando início a linhagem dos futuros reis de Portugal. Governou o condado português de 1128, após tomá-lo de sua mãe, até 1185 quando faleceu, tendo apenas em 1179 recebido o reconhecimento pelo poder pontifício do título régio e da independência do território. 233

Conhecido por suas vitórias militares contra os povos de religião islâmica na guerra de Reconquista, por unificar o território que viria a ser Portugal e torná-lo independente do reino leonês, seu retrato é muitas vezes controverso, oscilando entre Afonso I, o fundador, que recebeu ajuda diretamente de Deus durante a Batalha de Ourique (1139), e Afonso Henriques, “caudilho"234 rebelde contra a hierarquia a qual articulava-se, de humor irascível, violento, que fazia acordos com aliados e inimigos e que costumeiramente não os cumpria.

D. Afonso Henriques governou o território por 51 anos (1128-1179) sem o reconhecimento jurídico perante a Igreja e o papado, e sem ritual de consagração e unção régias. Conforme a historiografia tradicional (MATTOSO, 2014, p. 120-260), D. Afonso passou a intitular-se "Rei pela Graça de Deus" a primeira vez na Carta de

\footnotetext{
${ }^{233}$ SANTOS, Maria Fernanda Ribeiro Tomé Miranda dos. A Construção da autoridade legítima de D. Afonso Henriques de Portugal (1140-1185)/ Maria Fernanda Ribeiro Tomé Miranda dos Santos-2018. Orientador: Prof.a Dr. a Tânia Maria Tavares Bessone da Cruz Ferreira. Coorientador: Prof. a. Dr. a. Bruna Soalheiro Cruz. Dissertação (mestrado)-Universidade Estadual do Rio de Janeiro. Programa de Pós-Graduação em História.

${ }^{234}$ Termo encontrado para referenciar o duque na IVa. Crónica Breve de Sta. Cruz. Caudilhamento: Ofício, dignidade, ou distinção de um chefe militar, que seria a primeira personagem da tropa ou esquadra. Caudilho: Guia, Capitão. VITERBO, Joaquim de Santa Rosa de. Elucidario das palavras, termos e frases, que em Portugal antigamente se usaram, Volume I. 3a. Ed. Publisher, A. J. Fernandes Lopes, 1865. Original from, Oxford University. Pg. 178. Disponível em: http://purl.pt/13944/4//-14591-v/l-14591-v_item4/l14591-v_PDF/I-14591-v_PDF_24-C-R0090/I-14591-v_0000_capa-capa_t24-C-R0090.pdf
} 
confirmação e couto ao presbitero $D$. Nuno Gonçalves da Ermida de St ${ }^{\underline{a}}$. Marinha de Panóias (1140),235 não voltando a utilizar títulos como princeps e infante. ${ }^{236}$

Entretanto, sua divulgação como herói nacional se realiza após o seu tempo histórico, através das compilações ${ }^{237}$ da sua trajetória em Crónicas do século XIV, a pedido da recém instaurada Dinastia de Avis, alicerçando um relato de fundação centrada na lendária Batalha de Ourique (1139) e projetando-se diacronicamente até sua primeira tentativa de canonização no século XVI.

Destaca-se que as fontes documentais produzidas durante o seu reinado são cartas de doação, Couto, Forais e Anais, com breves registros dos fatos redigidos por clérigos. O único relato descritivo que chegou a nós e escrito durante o governo de Afonso Henriques, em que o mesmo é um dos protagonistas, é a "A Conquista de Lisboa ao Mouros em 1147. Carta de um cruzado inglês" (1147) escrita pelo monge Osberto.238

${ }^{235}$ AZEVEDO, Rui Pinto de. Documentos Medievais Portugueses, Documentos Régios, Documentos dos Condes Portucalenses e de D. Afonso Henriques. (Volume I, Tomo I e II) Lisboa: Ed. Academia Portuguesa de História, 1958. (Consultado em 06/10/2015)

${ }^{236}$ Maria João Guerreiro, em sua dissertação a respeito da intitulação régia de Afonso Henriques e seu filho Sancho I, optou por uma abordagem diplomática dos títulos, buscando analisar em um rol de documentos jurídicos, as alterações dos modos de nomear o rei, com ênfase nos chanceleres responsáveis pela escrita na corte. A autora afirma que, das seis fórmulas de intitulação de Afonso Henriques analisadas, "Ego Alfonsus Portugalensium rex", referenciando o território, é a mais utilizada, e " Ego egregius rex Alphonsus "Dei vero providentia totius provincie Portugalensium princeps" a mais completa. GUERREIRO, Ma. João P. Santos. Por Graça de Deus, Rei dos Portugueses. As Intitulações Régias de D. Afonso Henriques e D. Sancho I. 2010. 220 fl. Dissertação (Mestrado em Estudos Medievais). Lisboa: UAB - Universidade Aberta Pública Digital, 2010. Disponível em: http://hdl.handle.net/10400.2/1584

237 Conforme afirma a historiadora Kátia Michelan em sua dissertação de mestrado no qual busca comparar três versões da trajetória de Afonso Henriques, escritas cronísticas e em língua vernácula, a reutilização de fontes posteriores era modelar a arte trovadoresca medieval e substancial à escrita da história no fim do período medieval português. A compilação, perfil da produção cronística medieval, instrumentava uma fonte principal a outros documentos que, para o cronista, propiciava informações que este concebia como verdades sobre o passado. MICHELAN, Kátia Brasilino. Três Histórias de Afonso Henriques. Compilação, Reprodução e Reconstrução de uma Trajetória e uma Imagem. 2004. Dissertação (Mestrado em História) Universidade Estadual Paulista "Julio de Mesquita", Programa de Pós-graduação em História da Faculdade de História, Direito e Serviço Social. Franca, São Paulo. 2004

238 Tive a oportunidade de consultar A Conquista de Lisboa ao Mouros em 1147. Carta de um cruzado inglês, pela tradução do original em latim para português pelo Dr. José Augusto de Oliveira. Entretanto, devido aos limites a que é necessário se ater, e considerando a riqueza da narrativa, quantidade de detalhes, reprodução de discursos diretos e acordos como o pacto entre D. Afonso Henriques e os Cruzados, ou entre D. João Peculiar e os habitantes de Lisboa, assim como as várias contendas internas do exército cristão e o tom moralizador da obra, a tal ponto, que impossibilita neste trabalho abordar a narrativa de forma profunda, problematizada em seus múltiplos aspectos e com uma discussão 
Entendemos que o político configura-se no processo litigioso da elaboração de normas de participação, explícitas e implícitas, que definem e regulam a vida da cidade. Os documentos pertencentes à chancelaria real possuem caráter normativo: são cartas de couto e doações que definem os limites da terra ao beneficiário ou população livre, estabelecendo regras de organização militar, tributos e direitos. Para este artigo utilizaremos as cartas de correspondência entre D. Afonso Henriques e o Papa Lúcio II.

Conforme Quentin Skinner (2000), ao explicarmos as ações dos agentes históricos, é necessário considerar seu vocabulário normativo, pois se configura como um dos fatores determinantes das ações humanas, inclusive na análise de seu comportamento político e limitações. Destaca o autor que uma teoria política secular dissociada dos valores da ética e moral cristãs, só ocorreria no final do século XV. O poder espiritual e temporal na sociedade cristã medieval até os séculos XIV-XVI (KRITSCH, 2004, p. 110; ULLMANN, 1971), provém e é distribuído por Deus, que confiou as chaves celestes ao herdeiro de Pedro, o Sumo Pontífice. (KRITSCH, 2004, p.110 apud ULLMAN, 1971)

\section{Considerações sobre a origem do poder medieval: 0 rei e o Papa}

O rei ungido e coroado é o ideal de monarca cristão que prevaleceu durante o período do século V ao XV, não sendo, no entanto, concebido como um padrão. Fazê-lo seria negativizar diversas monarquias, principalmente hispânicas, ${ }^{239}$ que de fato ocorreram fora de tal modelo, como o próprio Afonso Henriques. Todavia, esse ideal de realeza com vínculos sobrenaturais com Deus, Cristo e os perfis de reis das escrituras bíblicas foi utilizado como recurso de afirmação e legitimação do poder em

historiográfica diversificada, principalmente a respeito de seu autor. In: OLIVEIRA, José A. (trad) A Conquista de Lisboa ao Mouros em 1147. Carta de um cruzado inglês. Apres. José da Felicidade Alves. Col. Cidade de Lisboa, Lisboa: Ed. Livros Horizonte, 1989.

${ }^{239}$ MARAVALL, J. A. El concepto de España em la Edad Media. Madrid: Centro de Estudios Constitucionales, 1981. Cf. RUCQUOI, Adeline. História Medieval da Península Ibérica (Introdução). Lisboa: Editora Estampa, 1995. 
diversificadas formas, conjunturas e momentos, tanto pela Igreja, quanto pelas monarquias.

O historiador Marc Bloch (1993), ao investigar o caráter sacro e miraculoso da realeza medieval francesa e inglesa, corrobora que o cerimonial hebraico do antigo testamento, no qual acredita-se que propagou a unção régia a partir do século VII, não se limitava exclusivamente aos reis, configurando um processo que transfere um caráter sagrado a algo ou alguém que pertencia ao terreno. Para o autor era consenso que a santidade real só existia a partir da unção, ritual que estabelecia a ligação do governante com o divino. Compreende-se que o rei é apenas um instrumento e intermediário de Deus, mas os milagres 240 que supostamente os monarcas realizavam eram feitos por Deus. (BLOCH, 1993, p. 130-132).

Deste modo a unção era a solenidade régia plena, conferindo ao rei ou imperador a justificativa biblico-jurídica cristã e o caráter de sagrado originalmente atribuídos aos reis da antiguidade. (BLOCH, 1993, p. 151-153.)

De acordo com Bloch (1993), a "unção-sacramento" justificada por teólogos de importância como S. Agostinho, o Anônimo de York, S. Bernardo, entre outros, marcava a entrada dos reis em uma vida mística, uma transformação espiritual, atribuindo a sagração régia poderes similares aos de purificação dos pecados que possuía o batismo, e tornava o homem um christianus. (Idem, p. 154.)

Logo o rei que possuía poderes taumaturgos reafirmava e legitimava seu direito régio, distinguindo-o dos reis comuns ou mesmo de barões. Este traço viria a ser um fator de prestígio particular entre os reis franceses e ingleses. Ernest Kantorowicz (1957) discute a doutrina cristocêntrica da realeza com base nos escritos do século XII do

\footnotetext{
${ }^{240} \mathrm{O}$ poder milagroso dos reis inicialmente era entendido como resultado da predestinação familiar. A partir da época carolíngia, esta virtude sagrada passou a ser atribuída à unção. Logo, conforme Bloch (1993), entende-se, uma espécie de complementariedade entre estas duas concepções, na medida em que para o homem medieval, o mundo temporal e o espiritual se correlacionam constantemente em complementariedade.
} 
Anônimo Normando, ${ }^{241}$ consistindo na ideia de que o monarca seria uma persona geminata, tal como o próprio Cristo, conjuntamente humano e divino. Entretanto, diferentemente da segunda pessoa da Trindade, que é divino por natureza, o rei tornarse-ia divino pela Graça. De acordo com o autor, quando o Normando escreveu seus tratados, o conceito do rei como pessoa dotada de qualidades espirituais ainda progredia e estava longe de passar do seu auge. Partindo do Antigo para o Novo Testamento, o historiador inicia suas considerações com as unções dos reis de Israel, os christi, os reis ungidos do Antigo Testamento, que haviam previsto a chegada do verdadeiro Christus régio. Após o advento de Cristo, sua ascensão e exaltação como 'Rei da Glória', a realeza terrena passaria constantemente por uma transformação e receberia sua função própria na economia da salvação. Deste modo o rei atuava como uma persona mixta, Ihe sendo atribuído, conforme afirmam também Bloch (1993) e Ullmann (1971 p.124), uma certa competência espiritual como manifestação de sua consagração e unção (KANTOROWICZ, 1998).

Destarte Kantorowicz (1953) ratifica que, por um breve período, o rei torna-se "deificado" em virtude da graça, ao passo que o Rei celeste é Deus eternamente por natureza. A contradição abordada entre natureza e graça era comumente utilizada para indicar não só que a fragilidade da natureza humana era remediada pela graça, mas concomitantemente, que a graça incentivava o homem a participar também da natureza divina.

Neste último sentido, o paradoxo entre ambos constituía de fato no condutor para a remota "deificação" cristã do homem em geral, e não apenas para os reis consagrados e ungidos. O anônimo, no entanto, sobrepunha essa "divinização pela graça" preferencialmente ao rei, como manifestação de sua unção e do ato ritual de

\footnotetext{
${ }^{241}$ Escrito provavelmente no início do século XII, o Tractatus Eboracensis, cujo autor desconhecido é comumente denominado Anônimo de York ou Normando, consiste em obra com trinta e um opúsculos, nos quais os De Consecratione Pontificum et Regum e Apologia Archiepiscopi Rotamagensis. Principalmente tratam da questão. In: SOUZA, José Antônio de C. R. de. O reino de Deus e o reino dos Homens: as relações entre os poderes espiritual e temporal na Baixa Idade Média (da Reforma Gregoriana a João Quidort). Porto Alegre: EDIPUCRS, 1997, p. 53.
} 
consagração, e utilizava a antítese para sublinhar que a "eminência de deificação" favorecia o rei de um corpo de graça pelo qual se tornava "outro homem", superior.

Conforme Walter Ullmann (1971, p. 121) o problema da realeza na Idade Média era a origem do seu poder, e a expressão Rex Dei Gratia, expressava a concepção descendente de governo pelo rei. ${ }^{242}$ A função do rei, ao depender da Graça divina, adquiria um caráter sagrado pois ligava-se estreitamente com Deus, e distanciava-se do povo que anteriormente o havia eleito.

Deste modo, a concepção de "Graça" foi instrumento de afirmação particular e determinante do poder secular, relacionada com a tradição e significado do título régio que identifica o monarca como escolhido por Deus, e que foi utilizado por Afonso I, conforme dito, sem a sanção dos pontífices contemporâneos ao seu governo até 1179 . Considerando pela perspectiva do papado, a norma fundamental era o "princípio ativo da indivisibilidade", no qual as ações e funções do indivíduo batizado não se dividia na Idade Média de forma compartimentada, sejam estas religiosas, morais, políticas, econômicas, culturais, entre outras.

Relevava-se a totalidade do indivíduo cristão que obedecia apenas a uma norma, a da Igreja e, para esta, toda ação teria uma interpretação cristã e era motivada por normas cristãs. Sendo incluso nesse princípio de indivisibilidade ou totalidade, o pensamento de que as ações terrenas refletem no mundo celestial e no objetivo de ordenar a sociedade em busca da salvação.

Nesta premissa, a união de todos os cristãos era uma unidade indivisível e no qual sua coerência residia na adesão a suas normas derivadas da fé cristã. Os poderes Petrinos abrangiam a todos, ninguém e nada estavam fora de sua jurisdição, concepção

\footnotetext{
242 Durante o Século $V$, os imperadores bizantinos, passaram a utilizar imperator Dei gratia em substituição ao divus imperator, simbolizando deste modo que não era em si mais divino, e seu poder não provinha mais do populus e sim de Deus. No entanto, a fórmula Dei Gratia era utilizada um século antes dos imperadores pelos bispos. Desde o século VIII tal fórmula tornou-se usual no Ocidente a partir de Carlo Magno.
} 
fundamentada pela bíblia de que os poderes de Pedro foram delegados por Cristo, e estes se exerciam sobre todos os homens batizados.

De acordo com o historiador Walter Ullmann, o Papa herdou de São Pedro a clavi regni coelorum, também designada claves juris, ou seja, as chaves do reino dos céus, recebidas por este de Cristo e com elas o poder de atar e desatar, ligar o cristão e as ações no mundo aos céus. (ULLMANN, 1971, p. 41). Paolo Prodi (2005) em sua obra a respeito da história e teoria do direito e do ordenamento jurídico no ocidente, corrobora sobre a aplicabilidade do conceito de ordem dentro da sociedade cristã como noção fundamental do universo religioso, físico, moral e jurídico. Conforme o autor, é a ordem que regula a relação entre os homens, e entre os homens e Deus através da culpa, ou do local de reconhecimento da culpa, e no qual afirma que a culpabilidade se estrutura como um processo de inclusão/exclusão, resultando no lugar da soberania e do poder. Deste modo o cristianismo sobre influência hebraica, inovou ao introduzir o conceito de pecado como culpa em relação ao Deus. (PRODI, 2005, p. 16-18.)

Considerando que o mundo medieval ocidental se divide em duas esferas distintas e correlacionadas, o sagrado e o profano, o puro e o impuro, o admitido e o proibido, a linha divisória que separa essas esferas polarizadas, conforme Paolo Prodi, é a lei. A profecia e a espera do messias, acrescenta paralelamente o conceito de pecado como culpa, como infidelidade a Deus e ao pacto, no qual a expiação só pode ser encontrada no espaço profético em que a justiça do homem é medida com a justiça de Deus. Resulta-se deste modo, o que Prodi denomina "legalismo", cujo qual toda transgressão da lei é pecado e este tende a absorver todo erro ou toda infração, com extensões progressivas desde as primeiras faltas rituais até os mais complexos mandamentos éticos (PRODI, 2005, p. 19 e 20). Logo, a contínua referência ao pecado, à misericórdia e ao perdão nos escritos que o autor denomina "neotestamentários", resulta na concessão do poder de interpretar e concretizar o poder divino à assembleia dos discípulos (a Igreja), instituído por Cristo o sacramento da penitência através da claves regni coelorum. (Idem, p. 22) 
Desta maneira constitui-se um foro, tanto interno da consciência quanto externo das ações, que se torna singular a justiça humana, não que coabitem dois sistemas de normas dentro da comunidade cristã, mas da constituição de uma estrutura alternativa em relação a justiça política. Destarte, o Papa apresentava uma concepção de monarquia ou Principatus papal, (ULLMANN, 1971, p. 43) estabelecendo que herdara de São Pedro poderes de caráter monárquicos, aparecendo tal perspectiva pela primeira vez na Espanha no século IV. Além disso, a sucessão petrina se relacionava ao status jurídico delegado por Cristo, independente das características pessoais do papa. Todavia, ao retomarmos brevemente as discussões a respeito da auctoritas e potestas, ${ }^{243}$ relembremos que tal questão principiou-se com o Papa Gelásio I, no Concílio de Calcedônia em 451, no qual enunciou a posteriormente designada "doutrina dos dois poderes" (ARNALDI, 2006, p. 567-589).

Estabeleceu-se com esta doutrina a concepção de que duas forças governavam e eram essenciais para a ordem divina no mundo terreno, a auctoritas sagrada dos pontífices, ${ }^{244}$ conceito compreendido aqui como a fonte própria do poder, una e indivisível, do qual o poder (potestas) dos reis, duces e imperadores é uma parcela desta, e abaixo em dignidade à autoridade do Papa. Esta divisão de poder e o fundamento filosófico e teosófico a partir de Gelásio I, 245 com influências neoplatônicas,

\footnotetext{
${ }^{243} \mathrm{Em}$ português e na terminologia atual, estes vocábulos são sinônimos, no entanto, conforme Strefling, em latim e no Direito Romano possuíam significado distinto. STREFLING, Sérgio Ricardo. Igreja e Poder: plenitude do poder e soberania popular em Marsilio de Pádua. Porto Alegre: EDIPUCRS, 2002. p.25.

${ }^{244}$ No entanto, o papa possui a plenitudo potestatis que se relaciona a concepção de consortium potentiae ou uma relação de poder entre Cristo, Pedro e Papa. Tal debate tem seus pormenores ao dividir-se em potestas jurisdictionis, referente aos assuntos jurídicos, aqueles que dentro da concepção bíblica e papal, pertencia ao pontífice pela herança petrina, e a potestas ordinis, relacionado com os assuntos sacramentais, consistindo na qualidade de sacramento carismática própria do papa, como o poder de sagrar um bispo (ULLMANN, 1971, p. 44-46).

245 Seguindo o pensamento de Agostinho e Crisóstomo, o papa Gelásio I, escreveu diretamente ao imperador a função e divisão do poder entre ambos, com superioridade do espiritual. Por conseguinte, Gregório o Grande, ou Magno (aprox. 540-604), foi papa e posteriormente canonizado, sendo um dos doutores da Igreja responsável por extensa obra, no qual destaca-se "Dialogos". Escrevendo como Agostinho, em um conturbado período de guerras entre Roma, godos e francos, Gregório defendia a união entre a monarquia e a Igreja em assistência mútua, buscando alcançar a ordem e unidade cristãs.
} 
fundamentaram a teoria papal e a concepção descendente do governo nos séculos precedentes.

\section{O significado da Graça}

Em uma acepção simples, a palavra graça significava privilégio, concessão, ${ }^{246}$ favor, ou algo que quem o recebia não tinha originalmente direito. A “Graça de Deus" é um dos primeiros princípios da teologia cristã, mencionado no início do Livro Gênesis, e relaciona com temas conhecidos e debatidos na Idade Média como a Queda de Adão e Eva (e do homem), o Pecado Original, Redenção, a Natureza e a punição/benevolência de Deus. Tais temas, assim como a "graça", sua evolução e posterior aplicabilidade na teoria política do papado e do reino, passou pelo crivo de expoentes pensadores e teólogos do período Medieval.

Dentre os teólogos e pensadores que debateram as múltiplas interpretações da temática da "Graça" nas escrituras bíblicas, destacamos o bispo Agostinho de Hipona (354 d.C - 430 d.C). ${ }^{247}$ Abordando a antítese "Natureza x Graça", Agostinho em seu Tratado sobre o Livre-arbítrio, introduz a noção de pecado original herdado de Adão, no qual o homem perdeu sua inocência e bondade, que o bispo denomina "Natureza Primeira", própria da criação divina, para tornar-se um ser manchado pelo pecado, de "Natureza Segunda". Logo, o homem possui a necessidade de Salvação concedida pela misericórdia de Deus através de sua Graça, que é um auxílio ao livre arbítrio, a vontade do homem, a fazer o bem e ter necessidade do bem.

\footnotetext{
${ }^{246}$ Atentamos ao "princípio de concessão" que por logística exclui o direito a coisa concedida, e aplicado pelo papado, soma-se a concepção de que todo poder dentro da comunidade cristã é um poder provindo de Deus e concedido pelo pontífice.

${ }^{247}$ Agostinho de Hipona ou Santo Agostinho, foi bispo da cidade de Hipona, província romana na África. Pertencente a patrística medieval, fez parte dos pensadores cristãos latinos e seus escritos assomam à influência do Direito Romano e da cultura clássica, com o legado judaico-cristão extraído dos escritos de Paulo, sendo a Cidade de Deus, sua obra mais divulgada.
} 
Para Agostinho toda ação humana é graça divina, convite de Deus, e a liberdade condiz em agir conforme essa graça. ${ }^{248}$ Agostinho defende ainda que a Graça é fruto da vontade e liberdade do amor de Deus, e concedida por Ele independentemente dos méritos e ações dos homens, cujo qual não podem ser salvos sem seu auxílio. O livre arbítrio não é suficiente para o homem alcançar a perfeição, somente o alcançará com o auxílio da graça divina. ${ }^{249}$

Deste modo, Deus deu suas leis a humanidade através dos reis, considerando o ofício real como um ofício eclesiástico e a Igreja, um só corpo. Assim, em uma concepção teleológica, o governante estava a serviço dos preceitos da Igreja, que buscava a salvação de todos os seus membros. Conforme anteriormente exposto à dissipada concepção do rei ideal como um homem acima dos demais, em capacidades militares, políticas, valores morais (respeitando as particularidades sociais e períodos distintos), o mais perfeito entre os homens que governa, acrescentasse-a as ideias agostinianas, inaugurando o que nos séculos posteriores se firmará como noção do papado da Graça divina, uma concessão e benção ao rei, e o que o legitima, através do ritual de unção e entrega de insígnias.

João Crisóstomo (cerca de 354 a 407 d. C), patriarca de Constantinopla em 397 e contemporâneo de Agostinho, formulou um princípio de separação de poderes e da superioridade do espiritual sobre o temporal, afirmando que ao rei foram confiados os corpos e ao sacerdote as almas. Esse pensamento será, conforme Michel Senellart (2006), retomado no século VII sobre influência do agostinianismo.

No entanto, Isidoro de Sevilha releva-se dentro de tais concepções, pois pertence ao âmbito do que viria a ser o território peninsular e foi próximo a monarquia visigoda.

\footnotetext{
${ }^{248}$ Santo Agostinho escreve em um momento de pertubações no centro romano, causados pela expansão do cristianismo entre os pagãos ainda existentes e com o saque de Roma por Alarico. Devido à fragilidade que o Império Romano se encontrava, o bispo de Hipona via a influência da Igreja no império necessária para que as duas instituições garantissem a paz.

249 LEITE JÚNIOR, Pedro G. da Silva; SILVA, Lucas Duarte da. (org.) Santo Agostinho: Reflexões e estudos. (Série Filosofia) Porto Alegre: Ed. EDIPUCRS, 2014. 294 p. Cf: COUTINHO, Maria da Graça Pereira. “A graça e o tempo em Santo Agostinho". Didaskalia. Lisboa. ISSN 0253-1674. $31: 2$ (2001) 27-70 p. Disponível em: http://hdl.handle.net/10400.14/18646.
} 
Sobre influência de Agostinho e Gregório, Isidoro escreveu um perfil do príncipe ideal, vinculado a preceitos morais e cristãos e às concepções políticas teleológicas anteriores, nas quais a realeza perfeita estaria a serviço da Igreja. Por conseguinte, Isidoro de Sevilha elaborou uma enciclopédia do conhecimento antigo em sua Etymologiae, inacabada, porém conforme Senellart, uma síntese da cultura greco-romana e do pensamento cristão, com influências diversificadas até o século XIV. Inspirando-se inicialmente em Recaredo (559 d.C-601d.C), governante que se converteu e oficializou o cristianismo no reino visigodo, o mesmo representaria o rei visigodo-cristão modelar, com características favoráveis a um bom governante (virtus).

Ao dissertar sobre reger, rei e reino, Isidoro relaciona reger e corrigir, atribuindo uma conduta moral, função e legitimidade ao título de rei, no cual o governante deve agir com retidão moral para ser apto ao título régio, e se pecar deve perdê-lo. Tal pensamento tem raízes nos debates agostinianos sobre o pecado, a dominação da própria carne e a correção dos impulsos. Cita-se Isidoro:

\footnotetext{
A palavra reino (regnum) vem de rei (a regibus). Com efeito, do mesmo modo que rei é tirado de reger (a regendo). (...) Do mesmo modo que sacerdote (sacerdos) vem de santificar (santificando), rei vem de reger. Ora, não se rege se não se corrige (SENELLART, 2006. p. 70. Grifo nosso).
}

Sobre as raízes germânicas e análise etimológica por Isidoro de rei, Senellart afirma que no vocábulo kun-ing-az, o radical kun significa família, raça, e a latina (rex), do nome do rei, referindo-se em germânico e em latim a noções divergentes. Kun relaciona-se com o pertencimento a uma raça, a laços de sangue. Em rex, prevalece a ideia de correto cumprimento das obrigações e dos ritos. (SENELLART, 2016, p. 70 e 71)

Desta forma, para o bispo de Sevilha a realeza como instituição estava a serviço da causa cristã, da vontade de Deus. Logo seu poder originava de duas vertentes, Deus e o povo cristão. É Deus que dá o poder, mas o rei é convocado pela comunhão de fiéis, e a Igreja, o regnum Christi. 
Considerando o perfil eletivo da monarquia visigoda pagã anterior a Recaredo, Isidoro une em sua teologia política cristológica, a aprovação popular com o sancionamento divino, só de Deus provém o poder real.

De acordo com Pâmela Michelette (2013) tal concepção descendente de poder nos escritos isidorianos é perceptível quando o bispo referencia o rei visigodo Suintila (588 d.C-633 d.C), utilizando a fórmula "gratia diuina". Logo, dentro das premissas eclesiásticas com fundamentos paulinos, o que se é não o devemos a nossas conquistas ou méritos pessoais, mas pela 'Graça de Deus', o conferimento do ofício real era um benefício, uma gratia, o que impossibilitava o rei de exigir sua aquisição como um direito, sendo um favor divino o apanágio de ocupar o trono.

A implícita ideia de concessão da 'graça cristã' relaciona-se com a de 'graça real' como um benefício e com a perspectiva de que o direito e o poder se ramificavam deste. Os súditos do rei não podiam exigir juridicamente direitos, eram detentores de privilégios, doações, ocupavam ofícios mas conforme a graça real (gratia regis), e assim como o monarca, sendo seu ofício uma prerrogativa da graça superior (divina ou real), o mesmo poderia perder tal direito quando em des-gratia. (ULLMANN, 1971, p. 124)

Deste modo, o ungimento real estabelecia o vínculo do rei com a divindade como um de seus vigários, nomeado de forma tangível. O óleo crismático sobre a cabeça e mãos era a ação concreta que tornava a graça divina manifesta no rei.

Observa-se, entretanto, que a partir do século XIII, as monarquias ocidentais passaram a contabilizar os anos de reinado a partir do ungimento e coroação, (Idem, p.124) conforme ocorreu com Sancho I, filho de Afonso Henriques, e não mais a partir da subida ao trono.

Portanto e conforme o princípio de idoneidade ou adequação presente na literatura papal do século $\mathrm{V}$ ao $\mathrm{XV}$, um ofício só poderia pertencer a alguém com capacidade para desempenhar as funções que o cargo compreendia. Tal idoneidade ou capacidade se relacionava com a utilidade dentro do corpo cristão. Logo, a abstenção 
de um ofício pelo pontífice, sendo este real ou episcopal, se referia a um padrão objetivo de utilidade. (ULLMANN, 1971, p. 69)

De acordo com os postulados pontifícios a função útil do príncipe, portador do gladium, segundo as palavras de Paulo, era combater o mal, sendo este mal no mundo designado pelo pontífice, que possuía sciencia, conhecimento para determinar o que era o mal e o pecado.

Deste modo, dentro do ponto de vista dos princípios papais, o rei não era autônomo em assuntos que afetavam a estrutura da Igreja e este, almejando ser um príncipe católico, deveria respeitar os ditames do papa, sobre pena de incorrer em excomunhão ou deposição. Assim sendo, o rei que se sujeitava ao papa aumentava sua honra e liberdades, o príncipe secular era, deste modo, concebido como um órgão instituído pela divindade para auxiliar o papa em sua função de governante do corpo cristão.

Considerando tal incumbência do rei e a propaganda cristã contra os mouros, estes como a representação do mal, verdadeiros inimigos da cristandade e da fé cristã, tanto na Terra Santa quanto na Península Ibérica, D. Afonso Henriques, apesar de conhecido como o intrépido guerreiro, combatente de mouros, e autointitulado como Miles Sancti Petri, estabeleceu pactos de tréguas com o califa Ibn Wazir, que dominou Lisboa e Santarém, Ibn Qasi, senhor da região de Silves e 'Ali al-Wahibi, senhor de Tavira. O "Chronicon Lusitano" e os "Anais do Rei Afonso" aludem que, a partir de 1144, Lisboa e Santarém passaram a pagar "párias" ou tributo a Afonso Henriques. Em contrapartida, evitava sua invasão pelas tropas portuguesas. (Mattoso 2014, p. 205 e 206)

Por conseguinte, encontram-se referências a acordos de colaboração, tréguas nos conflitos em determinado momento e pagamento de tributos, entre ambas as partes, não sendo eventualmente cumpridos por D. Afonso Henriques que, conforme José Mattoso, possuía um acordo de trégua com Santarém que o rompeu dias antes de a invadir e conquistar em 1147. 


\section{As correspondências entre D. Afonso Henriques e o Papa Lúcio II através da Carta “Claves Regni Coelorum" de 1143 e a Bula "Devotionen tuam" de 1144}

A Carta "Claves Regni Coelorum" aqui abordada, foi emitida por D. Afonso Henriques ao Papa Lúcio III em 1143. Conforme a tradição, seu original foi escrito em latim, possuindo uma lauda e três traduções diferentes, no qual optou-se pela versão contida na Monumenta Henricina. ${ }^{250}$

D. Afonso Henriques acorda neste documento o pagamento de tributo, 251 constituindo o território portucalense como 'censual' à Igreja de Roma e ao Papa Lúcio II, se referindo ao que o mesmo denomina como sua terra, na presença do Cardeal D. Guido e demais testemunhas. 252 O título da carta de D. Afonso aparenta ser o reconhecimento do governante português de que o Papa possui o poder das chaves, dado diretamente por Cristo e, consequentemente, aquele que tem a verdadeira autoridade e jurisdição de lhe reconhecer o título régio.

No entanto, designando-se antecipadamente perante o pontífice "por graça de Deus Rei de Portugal", o mesmo presta homenagem ao sucessor petrino, afirmando-se como um Miles Sancti Petri, 253 e tomando o Papa como "padroeiro e advogado" perante as dificuldades cotidianas e, almeja através dos conselhos pontifícios alcançar os "méritos da bem-aventurança".

\footnotetext{
${ }^{250}$ Reproduzida em: DIAS, Ana Patrícia; FERNANDES, Maria. "Em Torno da Claves Regni: do Texto à Simbólica do Miles Sancti Petri" 34 pp., Repositório da Universidade de Lisboa, Faculdade de Letras. Lisboa: Academia Portuguesa da História, 2009. Disponível em: http://hdl.handle.net/10451/8971 (Consultado em 29/10/2016).

${ }^{251}$ De acordo com o documento equivale a um "tributo anual de quatro onças de oiro."

${ }^{252}$ Confirmações de D. João Peculiar, Arcebispo de Braga de 1139 a 1175, D. Bernardo, Bispo de Coimbra entre 1128 e 1147, D. Pedro Rabaldes, Bispo do Porto de 1138 a 1145.

${ }^{253}$ A fórmula Miles Sancti Petri aparece inicialmente no Juramentus Regis proposto por Gregório VII, é comumente traduzida como Cavaleiro de São Pedro, pode ser compreendida como Vassalo de São Pedro, o que aparentemente corresponde as intenções da Igreja de obter protetores guerreiros, mas não a obriga necessariamente a proteger os mesmos, como solicita Afonso Henriques na carta Claves Regni. Ver: SALLES, Bruno Tadeu. "A intervenção gregoriana na cristandade: a vassalidade de São Pedro e o dominium pontifício" (1075-1088). Revista OPSIS, [S.I.], v. 11, n. 1, p. 210-233, set. 2011. ISSN 2177-5648. Disponível em: <https://www.revistas.ufg.br/Opsis/article/view/11087>. Acesso em: 24 mai. 2017. DOI:https://doi.org/10.5216/o.v11i1.11087.
} 
D. Afonso intitula-se ainda como "verdadeiro soldado de S. Pedro e do Pontífice Romano", e solicita a "defesa e auxílio da Sé apostólica" para que ele não seja obrigado a admitir em suas terras outro poder e senhorio, seja eclesiástico ou secular, que não o da Santa Sé e seus legados. Como resposta, em maio de 1144 o Papa Lúcio II emitiu a Bula "Devotionen tuam" a D. Afonso Henriques. O documento contém uma página, originalmente em latim e consultado a tradução de Diogo Freitas do Amaral. ${ }^{254} \mathrm{O}$ Pontífice inicia a carta com agradecimentos pela devoção de Afonso Henriques, denominando-o seguidamente de "ilustre duque", e salientando que por este estar a serviço de Deus contra os pagãos e ocupado com muitos negócios, o mesmo não pôde ir a sua presença (conforme enunciava os pressupostos gregorianos), confirmando porém que D. Afonso Henriques havia, através da figura do cardeal Guido prestado estas homenagens a seu antecessor, Papa Inocêncio III, e que, por meio de várias outras cartas do duque e de D. João Peculiar, arcebispo de Braga, no qual D. Afonso Henriques dedica sua terra e sua pessoa a proteção de Pedro.

Logo após relembrar as promessas de Afonso Henriques aos papas anteriores, Lucio II aceita o pagamento anual de quatro onças de ouro, pelo mesmo e seus herdeiros, recebendo-os entre os "herdeiros do príncipe dos apóstolos" para, com o auxílio do apóstolo Pedro, permaneçam sobre sua benção e proteção, tanto das almas quanto dos corpos, para que, defendidos contra inimigos invisíveis e visíveis, alcancem o reino celeste.

Este documento releva-se, pois, inicialmente é a única resposta papal às investidas de reconhecimento do título de rei por D. Afonso Henriques conhecida, e a afirmação de que o governante português tentou tal diálogo além da Carta Claves Regni. Destaca-se a saudação do Papa Lucio II, ressaltando que para o mesmo, D. Afonso

\footnotetext{
${ }^{254}$ AMARAL, Diogo Freitas. "Em que momento se tornou Portugal um País Independente". 2o Congresso Histórico de Guimarães: A política portuguesa e as suas relações com o exterior. Guimarães. Município de Guimarães, 1996. Vol. 2, 139-181. Disponível no web site do Arquivo Municipal Alfredo Pimenta. http://www.amap.pt/page/224\#i2. Consultado em 21/10/2016).
} 
Henriques é um dux, ${ }^{255}$ logo, sua terra o ducado portucalense e não um rei, como este havia afirmado na carta anterior ao mesmo pontífice e que o pagamento de tributo e vassalagem são aceitos, porém, não faz referência a afirmação de Afonso Henriques de não mais ser obrigado a aceitar outro poder, ou da honra deste como Miles Sancti Petri.

Observamos que, eventualmente cumprindo a função de combater os inimigos da Igreja, D. Afonso Henriques o fazia com o reconhecimento do papado como um comandante militar, um dux. Partindo do desígnio de Lucio II, os três papas que o precederam ${ }^{256}$ partilhavam da mesma concepção, na medida em que não houve reconhecimento de Afonso por estes, considerando o princípio de que os pontífices não estavam vinculados as decisões de seus antecessores, pois herdavam o trono diretamente de Pedro. Provavelmente isso é devido ao fato do dux português exercer a função de combater os mouros por interesse particular de expandir seu território sobre as fronteiras inimigas de forma legítima, conforme assegurava a Carta aos Príncipes da Hispânia de Gregório VII, ${ }^{257}$ mesmo sem o reconhecimento do título rex.

Concomitantemente à ideia de justiça, se relacionava a aplicação de normas dentro do corpo cristão, vinculadas aos poderes jurisdicionais do papa contidos na claves juris, a Igreja era a sede da justiça e contrariar suas normas, era opor-se ao direito

\footnotetext{
${ }^{255}$ Conforme Tácito em sua obra "Germania", no centro do entendido por esfera pública germânica, ao qual o mesmo denomina "assembleia", localiza-se um rei, "reges ex nobilitas", escolhidos pela nobreza e os "duces ex virtute sumunt", os duques pela virtude. Logo, os dux eram escolhidos por sua capacidade (ex virtude) em comandar o povo na guerra, não constituindo uma instituição fixa na sociedade, pois sua existência condiciona-se à questões bélicas. Sendo que tal cargo só poderia ser exercido por alguém de linhagem nobre ou um rex (possuindo este a nobreza hereditária e a virtude guerreira). Um líder hábil em comando, passava a possuir amplos poderes em contexto de guerra, sendo elevados por sua própria fortuna. Alguns dux foram chamados rex pelos romanos, mas um deles, Julius Civilis, de acordo com Tácito, fez um rito de juramento e foi, provavelmente, erguido no escudo como líder, deixando seu cabelo crescer e tingindo-o de vermelho em homenagem ao deus pórr. SANTOS, 2018, p. 106-107.
}

${ }^{256}$ Eugenio III 1145-1153/ Anastácio IV 1153-1154/ Adriano IV 1154-1159. Considerando que Alexandre III iniciou seu pontificado em 1159, ainda demorou 20 anos para emitir a Manifestis Probatum.

${ }^{257}$ A guerra de Reconquista na Península adquiriu status de Guerra Santa, após a indulgência prometida para aqueles que combatessem pela Cruz na Península, promulgada por Alexandre II, e ressaltada pela Carta de Gregório VII aos príncipes de Hispânia, na qual o pontífice incentiva o combate em nome de São Pedro, e do qual ouve ressonância no juramento de 1077 do duque Roberto de Guiscard (SALLES, 2011, p. 210). 
que possuía, sendo o opositor bispo ou rei, justificaria conforme Ullmann (1971, p. 76), que o pontífice declarasse falta de idoneidade do beneficiário do cargo.

Considerando que de acordo com a doutrina papal, o temporal não possui valor nem sustentação próprios se não sendo um meio para o fim da unidade cristã, a distinção categorizada de atividades (religiosas, políticas, sociais, entre outras) só contava se inserida pelo 'princípio de utilidade'258 na concepção indivisível da sociedade cristã.

Deste modo o importante era a conduta do cristão no mundo, que mesmo em âmbito temporal, tinha consequências na sociedade como um todo, o que significava que a jurisdição e o direito papal se relacionavam com as ações e a conduta dos cristãos, pois o pontífice estava autorizado e destinado a conduzir a comunidade de fiéis. Tal concepção de forma aplicada remete ao direito papal de excomungar e depor os reis e imperadores, na medida em que, estes reconhecem que seu poder é de origem divina com a fórmula "pela graça de Deus", o pontífice estava qualificado a julgar os príncipes temporais conforme sua conduta.

Se em relação ao temporal, a conduta do cristão era repreensível, não havia impedimento para o pontífice exercer tal jurisdição ou optar por não conceder a graça divina expressa no reconhecimento do título régio. No caso, sendo a deposição de um rei jurisdição papal, a mesma não era necessariamente uma ofensa a pessoa do rei, mas era o ponderamento pontifício de que o ofício real não estava em portador adequado. (ULLMANN, 1971, p. 76)

Recordamos aqui que Afonso Henriques aparentemente não cumpriu os juramentos de vassalagem que prestou ao imperador da Hispânia, tanto o de Guimarães ainda como infante (1127), como o Tratado de Tui (1137), o encontro de Valdevez (1139)

\footnotetext{
${ }^{258}$ Em 1245 o Papa Inocêncio IV destituiu Sancho II, bisneto de Afonso Henriques, como Rex inutilis por não participar ativamente da guerra de Reconquista e por querelas com o clero local, através da Bula Grandi non immerito. Assumiu então Afonso III, seu irmão como protetor do reino, com inicial apoio do clero, nobreza e mercadores, mas sendo posteriormente excomungado em 1268 até 1279 , ano de sua morte.
} 
e Zamora (1140), guerreando com Afonso VII por territórios ao sul da Galiza, aceitando homenagens de nobres vassalos ao Imperador. Além dos conflitos militares com seu suserano, ao pormenorizar os relatos sobre as relações entre a nobreza portuguesa e Afonso Henriques, algumas das narrativas sobre sua conduta moral podem ser controversas.

Deste modo, seria cabível a qualquer um dos pontífices durante seu governo intervir a favor de Afonso VII com a justificativa de manter a unidade e paz entre os cristãos sem ofender Afonso Henriques, assim como criticar ou proibir o uso do título régio pela chancelaria afonsina, na medida em que o Dux se reconhece como governante Cristão e que possui a Graça divina. A Carta Claves Regni Coelorum, ratifica ainda mais a questão, na medida em que manifesta deste o título o reconhecimento do "poder das chaves" pontifício, utiliza o conceito de Miles Sancti Petri e a fórmula "por graça de Deus Rei de Portugal".

Por conseguinte, a natureza do poder papal autorizava o pontífice transferir reinos, territórios, principados, todas as posses físicas à cristãos mais adequados, tornando-se uma concessão. O direito a propriedade privada do reino era considerado pelo papado como consequência da graça divina, estabelecida no ritual de coroamento e unção régios e no juramento real realizado concomitante ao rito.

Entretanto, conforme a historiografia do primeiro rei exposta anteriormente, não há registros de tal cerimônia, o que levaria a questionar o direito de Afonso Henriques a propriedade privada do território português ou justificaria sua busca pelo reconhecimento jurídico do pontífice através das correspondências com Lúcio II.

Observa-se que, deste modo, a inclinação de considerar a utilização da fórmula Dei Gratia no título régio apenas como um costume, elogioso a pessoa do rei ou diplomaticamente, seria desconsiderar uma longa linha de pensamento e influência que dividiu diversos teólogos e filósofos de ambos os posicionamentos durante todo o período medieval.

\section{Considerações finais}


Apesar das qualidades morais e bélicas vinculadas ao dux, ainda figurava a questão do sancionamento jurídico de sua autoridade, e a garantia da instância máxima de sua época, o papado, da hereditariedade de seu domínio e dignidade régia. A obediência à autoridade da Igreja romana e do pontífice era obrigação de todo cristão, principalmente do rei, devendo a salvação das almas a rendição à esta autoridade, vinculada diretamente a Deus.

Entretanto, independente do personagem real, constata-se que a chancelaria Afonsina utilizou uma estratégia para legitimar sua autoridade de forma perpétua e inquestionável, ao aplicar o conceito eclesiológico da Dei Gratia, junto ao título Rex em seus documentos jurídicos sem o consentimento da cúria romana. Tal conceito, validado e controlado através do ritual de unção e conforme interesse político da Igreja, reúne a concepção cristã do rei ser escolhido por Deus, príncipe cristão e de idoneidade moral.

Acredita-se que o uso do conceito da Graça, pertencente a uma longa linha de pensamento medieval, resultou na aceitação emocional, crença de que Afonso Henriques era de fato portador da graça divina, por ser homem de conduta exemplar e portador de valores morais cristãos, assim como de que pela obediência a sua autoridade recebida do divino se encontra a salvação.

\section{Referências}

\section{Documentação}

Carta de confirmação e couto ao presbítero D. Nuno Gonçalves da Ermida de Stä. Marinha de Panóias1 (1140) In: Documentos Medievais Portugueses, Documentos Régios, Documentos dos Condes Portucalenses e de D. Afonso Henriques (Volume I, Tomo I e II). Organização De Rui De Azevedo. - Ed. Academia Portuguesa de História Lisboa, 1958

Carta "Claves Regni Coelorum" de D. Afonso Henriques, dirigida ao Papa Lúcio II. 13 de Dezembro de 1143. In: Dias, Ana Patrícia; Fernandes, Maria. Em Torno da Claves Regni: do Texto à Simbólica do Miles Sancti Petri, 34 pp., Repositório da Universidade de Lisboa, 
Faculdade de Letras. Lisboa: Academia Portuguesa da História, 2009. Disponível em: http://hdl.handle.net/10451/8971. Consultado em 29/10/2016.

Bula "Devotionen tuam", do Papa Lúcio II a D. Afonso Henriques. 01 de Maio de 1144. In: AMARAL, Diogo Freitas. "Em que momento se tornou Portugal um País Independente." In 2 Congresso Histórico de Guimarães: A política portuguesa e as suas relações com o exterior. Guimarães: Município de Guimarães, 1996. Vol. 2, 139-181. Disponível no web site do Arquivo Municipal Alfredo Pimenta.(http://www.amap.pt/page/224\#i2.Consultado em 21/10/2016.

Bula Manifestis Probatum- 23 de Maio de 1179 In: GONÇALVES, Francisco Rebelo (Tradução da Bula "Manifestis Probatum") Lisboa: Academia das Ciências de Lisboa: [s.n.], 1981 ([Braga : Tip. Barbosa \& Xavier]). p. 53-55. In: Portugal, um estado de direito com oitocentos 1981. Disponível em: http://www.arqnet.pt/portal/portugal/documentos/ manifestis_probatum.html. Consultado em 29/10/2016.

\section{Bibliografia}

AMARAL, Diogo Freitas. "Em que momento se tornou Portugal um País Independente". 2 Congresso Histórico de Guimarães: A política portuguesa e as suas relações com o exterior. Guimarães. Município de Guimarães, 1996. Vol. 2, 139-181. Disponível no web site do Arquivo Municipal Alfredo Pimenta. (http://www.amap.pt/page/224\#i2.Consultado em 21/10/2016)

AZEVEDO, Rui Pinto de. Documentos Medievais Portugueses, Documentos Régios, Documentos dos Condes Portucalenses e de D. Afonso Henriques. (Volume I, Tomo I e II) Lisboa: Ed. Academia Portuguesa de História, 1958. Consultado em 06/10/2015.

BLOCH, Marc. Os Reis Taumaturgos. O caráter sobrenatural do poder régio, França e Inglaterra. São Paulo: Cia. Das Letras, 1993

COUTINHO, Maria da Graça Pereira. "A graça e o tempo em Santo Agostinho". Didaskalia. Lisboa. ISSN 0253-1674. 31:2 (2001), p. 27-70.

DIAS, Ana Patrícia; FERNANDES, Maria. "Em Torno da Claves Regni: do Texto à Simbólica do Miles Sancti Petri" 34 pp., Repositório da Universidade de Lisboa, Faculdade de Letras. Lisboa: Academia Portuguesa da História, 2009. Disponível em: http://hdl.handle.net/10451/8971 Acesso em 29/10/2016.

GUERREIRO, Mà. João P. Santos. Por Graça de Deus, Rei dos Portugueses. As Intitulações Régias de D. Afonso Henriques e D. Sancho I. 2010. 220 fl. Dissertação (Mestrado em Estudos Medievais). Lisboa: UAB - Universidade Aberta Pública Digital, 2010. 
KANTOROWICZ, Ernest. Os dois corpos do rei. Um estudo sobre teologia política medieval. São Paulo: Companhia das Letras, 1998.

KRITSCH, Raquel. "Rumo ao Estado Moderno: As raízes medievais de alguns de seus elementos formadores". Revista De Sociologia e Política. №. 23. (103-114) Nov. 2004.

LEITE JÚNIOR, Pedro G. da Silva; SILVA, Lucas Duarte da. (org.) Santo Agostinho: Reflexões e estudos. (Série Filosofia) Porto Alegre: Ed. EDIPUCRS, 2014.

LE GOFF, J.; SCHMITT, J. (org.) Dicionário Temático do Ocidente Medieval. Vol. 1. Tradução de Hilário Franco Júnior., São Paulo: EDUSC, 2006.

MARAVALL, J. A. El concepto de España em la Edad Media. Madrid: Centro de Estudios Constitucionales, 1981.

MATTOSO, José: D. Afonso Henriques. Ed. Círculo de leitores e Centro de estudos dos povos e culturas de expressão portuguesa, 2014.

MICHELAN, Kátia Brasilino. Três Histórias de Afonso Henriques. Compilação, Reprodução e Reconstrução de uma Trajetória e uma Imagem. 2004. Dissertação (Mestrado em História) Universidade Estadual Paulista "Julio de Mesquita", Programa de Pósgraduação em História da Faculdade de História, Direito e Serviço Social. Franca, São Paulo. 2004.

MICHELETTE, Pamela Torres. "Isidoro de Sevilha e a construção de um conceito de monarquia teocrática no reino visigodo". Revista Crítica Histórica, Ano IV, no. 7, julho/2013.ISSN:2177-9961.

OLIVEIRA, José A. (trad) A Conquista de Lisboa ao Mouros em 1147. Carta de um cruzado inglês. Apres. José da Felicidade Alves. Col. Cidade de Lisboa, Lisboa: Ed. Livros Horizonte, 1989.

PRODI, Paolo. Uma História da Justiça: do pluralismo dos tribunais ao moderno dualismo entre a consciência e o direito. São Paulo: Ed. Martins Fontes, 2005.

RUCQUOI, Adeline. História Medieval da Península Ibérica. Lisboa: Editora Estampa, 1995.

SALLES, Bruno Tadeu. "A intervenção gregoriana na cristandade: a vassalidade de São Pedro e o dominium pontifício" (1075-1088). Revista OPSIS, [S.I.], v. 11, n. 1, p. 210-233, set. $2011 . \quad$ ISSN 2177-5648. Disponível em: <https://www.revistas.ufg.br/Opsis/article/view/11087. Acesso em: 24 mai. 2017.

SANTOS, Maria Fernanda Ribeiro Tomé Miranda dos. A Construção da autoridade legítima de D. Afonso Henriques de Portugal (1140-1185)/ Maria Fernanda Ribeiro Tomé Miranda dos Santos-2018. Orientador: Prof.a Dr.a Tânia Maria Tavares Bessone da Cruz 
Ferreira. Coorientador: Prof.a. Dr.ạ. Bruna Soalheiro Cruz. Dissertação (mestrado)Universidade Estadual do Rio de Janeiro. Programa de Pós-Graduação em História.

SENELLART, Michel. As Artes de Governar. Do Regimem medieval ao conceito de Governo. Tradução Paulo Neves. São Paulo: Editora 34, 2006.

SKINNER, Quentin. As fundações do pensamento político moderno. São Paulo: Cia. Das letras, 2000.

SOUZA, José Antônio de C. R. de. O reino de Deus e o reino dos Homens: as relações entre os poderes espiritual e temporal na Baixa Idade Média (da Reforma Gregoriana a João Quidort). Porto Alegre: EDIPUCRS, 1997.

STREFLING, Sérgio Ricardo. Igreja e Poder: plenitude do poder e soberania popular em Marsílio de Pádua. Porto Alegre: EDIPUCRS, 2002.

ULLMANN, Walter. Principios de Gobierno y Politica em la Edad Media. Trad. (espanhol) Graciela Soriano. Madrid: Ed. Resta de Occidente. 1971. 